\title{
Resistance to monepantel in multiresistant gastrointestinal nematodes in sheep flocks in Rio Grande do Sul
}

\section{Resistência ao Monepantel em nematoides gastrintestinais multiresistentes em rebanhos ovinos no Rio Grande do Sul}

\author{
Pedro Marino Mallmann Júnior ${ }^{1}$; Raquel Fraga e Silva Raimondo ${ }^{2 *}$; Beatriz Riet \\ Correa Rivero'; $^{2}$ Luiza Rodegheri Jacondino ${ }^{1}$; Andressa Silveira Gonçalves ${ }^{1}$; \\ Brenda Oliveira Silveira ${ }^{1}$; Eneder Rosana Oberst ${ }^{2}$
}

\begin{abstract}
The excessive, indiscriminate, and continued use of anthelmintic drugs as control methods favors parasite resistance, and this phenomenon has been reported in Brazil and worldwide. The current status of parasite resistance to anthelmintic drugs in sheep flocks in Rio Grande do Sul was assessed by calculating the EPG count in the stool to estimate the prevalence of resistance to the anthelmintic drugs closantel, levamisole, fenbendazole, monepantel, and moxidectin in seven properties. The animals from each flock were randomly distributed in six groups according to the anthelminthic drug used, as follows: T1, levamisole; T2, fenbendazole; T3, monepantel; T4, moxidectin; T5, closantel; and T6, control. On day zero, fecal samples were collected, and each animal was treated with one anthelminthic drug. Fecal samples were collected again after 14 days to calculate the efficacy of each active principle. Coproculture was performed using a pool of fecal samples from each group on day 0 and 14 to identify the predominant genera and prevalence of helminths. The genera identified in the coprocultures were Haemonchus, Trichostrongylus, Oesophagostomum, and Teladorsagia. All flocks developed resistance to levamisole, fenbendazole, moxidectin, and closantel. Moreover, resistance to monepantel was found in four of the seven farms. These results demonstrate the critical situation of anthelmintic resistance in sheep flocks in Rio Grande do Sul and the need to adopt other integrated control measures in addition to anthelmintic treatment.
\end{abstract}

Key words: Gastrointestinal nematodes. Parasitic resistance. Monepantel. Haemonchus contortus. OPG. Sheep.

\section{Resumo}

Uso excessivo, indiscriminado e continuado de anti-helmínticos como métodos de controle favorece o desenvolvimento de isolados de parasitos resistentes, fenômeno relatado no Brasil e no mundo. Com o objetivo de verificar a atual situação da resistência anti-helmíntica em rebanhos ovinos no Rio Grande do Sul, foram realizados testes de redução da contagem de OPG nas fezes (TRCOF), a fim de estimar a prevalência de resistência parasitária em sete propriedades utilizando os seguintes antihelmínticos: closantel, levamisol, fenbendazol, monepantel e moxidectina. Em cada rebanho os animais

1 Discentes de Graduação em Medicina Veterinária, Núcleo RuminAção, Ensino, Pesquisa e Extensão em Ruminantes, Faculdade de Veterinária, Universidade Federal do Rio Grande do Sul, UFRGS, Porto Alegre, RS, Brasil. E-mail: pedrommjunior@gmail. com; lurodegheri@hotmail.com; dessasg@hotmail.com; brendasilveira.vet@live.com

$2 \operatorname{Prof}^{\text {as }}$ Dras $^{\text {as }}$, Núcleo RuminAção, Ensino, Pesquisa e Extensão em Ruminantes, Faculdade de Veterinária, Universidade Federal do Rio Grande do Sul, UFRGS, Porto Alegre, RS, Brasil. E-mail: rfraimondo@gmail.com; beatrizriet@hotmail.com; oberst@ufrgs.br

* Author for correspondence 
foram distribuídos aleatoriamente, respeitando a homogeneidade de categorias, em seis grupos, T1 levamisol, T2 - fenbendazol, T3 - monepantel, T4 - moxidectina, T5 - closantel e T6 - controle. No dia zero foram coletadas amostras de fezes e os animais foram tratados, após 14 dias foi feita nova coleta de fezes para calcular a eficácia de cada princípio ativo. A coprocultura foi realizada através de um pool de fezes de cada grupo no dia 0 e 14 para identificação dos principais gêneros e as suas prevalências. Os gêneros de helmintos identificados nas coproculturas realizadas foram: Haemonchus, Trichostrongylus, Oesophagostomum e Teladorsagia. Em todos os rebanhos foi diagnosticada resistência ao levamisol, febendazol, moxidectina e closantel, e, em quatro das sete propriedades foi encontrada resistência ao monepantel. Alerta-se para a situação crítica da resistência anti-helmíntica nos rebanhos gaúchos e a necessidade de se adotarem outras medidas de controle integrado além do tratamento exclusivo com anti-helmíntico.

Palavras-chave: Nematoides gastrintestinais. Resistência parasitária. Monepantel. Haemonchus contortus. OPG. Ovinos.

\section{Introduction}

The primary factors that interfere in sheep farming are the high prevalence of parasitic infections and the difficulty of effective control of gastrointestinal nematodes in small ruminants, and these factors jeopardize animal performance and well-being and increase mortality (FORTES; MOLENTO, 2013).

The short interval between treatments, suppressive treatments, rapid alternation of different active principles, introduction of animals with resistant parasites in the flock, and the excessive, indiscriminate, and continued use of long-acting anthelmintic drugs as control methods favor the development of isolates of parasites resistant to anthelmintic drugs, and this phenomenon has been reported in Brazil and overseas (ECHEVARRIA et al., 1996; NARI et al., 1996; BESIER; LOVE, 2003; WAGHORN et al., 2006; ROSALINSKI-MORAES et al., 2007; HOWELL et al., 2008; ALMEIDA et al., 2010; SCZESNY-MORAES et al., 2010; COSTA et al., 2011; HOLSBACK, et al., 2013; GEURDEN et al., 2014; GÁRCIA et al., 2016). These measures result in increased costs with ineffective treatments and may jeopardize sheep farming.

Relying on the development of new drugs to control parasites is risky because the drug development process tends to be slow. Monepantel, a drug derived from aminoacetonitrile, was launched in New Zealand in 2009 and Brazil in 2012. Monepantel is the first molecule of an entirely new chemical group to appear on the market after more than 25 years (KAMINSKY et al., 2008). Despite the recent development of monepantel, cases of resistance to this drug were observed in sheep and goats in New Zealand (SCOTT et al., 2013), Uruguay (MEDEROS et al., 2014), and Brazil in the state of São Paulo (ALBUQUERQUE et al., 2017; MARTINS et al., 2017) and Paraná (CINTRA et al., 2016).

The objective of this study is to evaluate anthelminthic resistance to five active principlesclosantel, fenbendazole, levamisole, moxidectin, and monepantel-and determine the efficacy of each drug in sheep flocks in Rio Grande do Sul.

\section{Materials and Methods}

The experimental protocols used in this study were approved by the Animal Research Ethics Committee of the Federal University of Rio Grande do Sul and were registered and approved under Protocol No. 30134.

The study was conducted from March to May 2016 in seven small and medium sheep flocks, with a mean number of heads of 236 sheep, with 55 sheep in the smallest flock and 813 animals in the largest flock. Three flocks were located in the central eastern mesoregion (Arroio do Meio, Bom Retiro do Sul, and Rio Pardo), three in the metropolitan mesoregion of Porto Alegre (two in Eldorado do Sul and one in São Pedro da Serra), and one in the 
southeastern mesoregion (Canguçu) of the state of Rio Grande do Sul. All flocks were destined for meat production using a semi-extensive production system, in which the sheep were raised on pasture and received supplementation of feed concentrate in the trough during the winter and for females in lactation (São Pedro da Serra and Canguçu), with the exception of one property in Eldorado do Sul (ES-2), where production was extensive. The raised breeds were predominantly Texel and crossbred, except in the property in Arroio do Meio, where Santa Inês was raised. The animals were raised according to the general and nutritional management of the property. The choice of properties took into consideration 1 . The flock size, according to the number of animals needed in each group; 2. Handling facilities; and 3. Absence of anthelmintic treatment for at least 30 days before the beginning of the study. Three farms had used monepantel (São Pedro da Serra, Canguçu, and Bom Retiro) but the interval from use to the first fecal collection was $>90$ days.

The status of anthelmintic resistance was assessed during two visits to each property. In the first visit (day zero), the study sample was divided into six groups, including one control group without treatment and five intervention groups, with the treatment of each group with one active principle. The sheep were chosen at random, respecting the homogeneity of each category, and the animals were weighed to determine the dosage of each drug. The animals were assigned as follows: group 1 (G1), treatment with levamisole hydrochloride $5 \%$ (oral solution, $\left.5 \mathrm{mg} \mathrm{kg}^{-1}\right)\left(\right.$ Ripercol${ }^{\circledR}$, Fort Dodge Animal Health); group 2 (G2), treatment with fenbendazole (oral solution, $5 \mathrm{mg} \mathrm{kg}^{-1}$ ) (Panacur $\AA$, Intervet); group 3 (G3), treatment with monepantel (oral solution, $2.5 \mathrm{mg} \mathrm{kg}^{-1}$ ) (Zolvix ${ }^{\circledR}$, Novartis); group 4 (G4), treatment with moxidectin ( $1 \%$ injectable solution, $\left.0.2 \mathrm{mg} \mathrm{kg}^{-1}\right)$ (Cydectin $\AA$, Fort Dodge Health Animal Ltd.); group 5 (G5), treatment with closantel (oral solution, $10 \mathrm{mg} \mathrm{kg}^{-1}$ ) (Diantel $\AA$, Hipra); and a control group (G6), which did not receive anthelmintic treatment. After separating the groups, fecal samples were collected directly from the rectal ampulla using procedure gloves. The fecal samples were individually transferred to plastic bags and conditioned in a cooled environment for counting the number of eggs per gram of feces (EPG) before treatment. After that, each sheep was treated with an anthelmintic drug as per assigned group. The sheep fasted for 12 hours before treatment.

The number of EPG was counted using the method of Gordon and Whitlock (1939), with modifications. The animals whose EPG count was $<200$ in the first stool examination were excluded from the study. The study sample is shown in Table 1. Fourteen to fifteen days after treatment, a second visit was made to the farm to collect fecal samples for the EPG count after treatment.

Table 1. Number of sheep before and after the first count of eggs per gram of feces (EPG) in each group. AM, Arroio do Meio; BRS, Bom Retiro do Sul; CA, Canguçu; ES1, Eldorado do Sul 1; ES2, Eldorado do Sul 2; RP, Rio Pardo; SPS, São Pedro da Serra.

\begin{tabular}{lccccccccccccc}
\hline & \multicolumn{1}{c}{ Number of sheep before } & \multicolumn{4}{c}{ Number of sheep after the first EPG } \\
\hline Sheep flocks & G1 & G2 & G3 & G4 & G5 & G6 & G1 & G2 & G3 & G4 & G5 & G6 \\
\hline AM & 15 & 15 & 15 & 15 & 15 & 15 & 6 & 5 & 9 & 4 & 6 & 6 \\
BRS & 15 & 15 & 15 & 15 & 15 & 15 & 5 & 4 & 6 & 6 & 8 & 4 \\
CA & 12 & 12 & 12 & 13 & 12 & 12 & 6 & 8 & 7 & 12 & 10 & 8 \\
ES1 & 17 & 15 & 15 & 9 & 11 & 9 & 12 & 6 & 11 & 7 & 8 & 7 \\
ES2 & 15 & 15 & 15 & 15 & 15 & 15 & 7 & 13 & 9 & 8 & 11 & 11 \\
& & & & & & & & & & & & continue
\end{tabular}


continuation

\begin{tabular}{lcccccccccccc} 
RP & 10 & 9 & 10 & 9 & 9 & 8 & 9 & 9 & 10 & 8 & 9 & 6 \\
SPS & 15 & 15 & 15 & 15 & 15 & 15 & 7 & 11 & 9 & 9 & 7 & 9 \\
\hline
\end{tabular}

AM-Arroio do Meio; BRS-Bom Retiro do Sul; CA-Canguçu; ES1- Eldorado do Sul 1; ES2- Eldorado do Sul 2; RP-Rio Pardo; SPS- São Pedro da Serra.

Group 1 (G1), treatment with levamisole hydrochloride (oral solution, $5 \mathrm{mg} \mathrm{kg}^{-1}$ ); group 2 (G2), treatment with fenbendazole (oral solution, $5 \mathrm{mg} \mathrm{kg}^{-1}$ ); group 3 (G3), treatment with monepantel (oral solution, $2.5 \mathrm{mg} \mathrm{kg}^{-1}$ ); group 4 (G4), treatment with moxidectin ( $1 \%$ injectable solution, $0.2 \mathrm{mg} \mathrm{kg}^{-1}$ ); group 5 (G5), treatment with closantel (oral solution, $10 \mathrm{mg} \mathrm{kg}^{-1}$ ); group 6 (G6), control group without anthelmintic treatment.

In both visits, coproculture was performed using a pool of fecal samples collected from each group on day zero and 14 to 15 days after treatment. The samples were analyzed using the method of Roberts and O'Sullivan (1950) to identify the main genera of helminths. It was not possible to perform coproculture in one of the properties, and therefore this property was not included in the analysis.

The anthelmintic efficacy of the formulations was estimated using the software RESO version 2.01 (Analysis Program CSIRO, Division of Animal Health, Glebe, NSW, Australia), in which the arithmetic mean of the EPG was used for all groups, calculating the confidence interval of the means. After that, the following classification was used according to Zajac and Conboy (2006): The drug was effective when the efficacy was $>90 \%$; drug was poorly effective when the efficacy was $80-90 \%$, and drug was ineffective when the efficacy was $<80 \%$.

In each farm, a manager answered a questionnaire on overall management, nutritional management, and management of helminth control, including the frequency of treatments, animal acquisition, pasture management, and criteria and rate of change of anthelmintic drugs.

\section{Results}

Theresultsindicated that therewasmultiresistance in all evaluated properties. The four commonly used anthelmintic drugs - closantel, fenbendazole, levamisole, and moxidectin-presented poor efficacy in all analyzed farms. Monepantel had high efficacy ( $>99 \%)$ in reducing the EPG in three flocks (43\%) and low efficiency in two flocks (88\% in ES1 and $87 \%$ in SPS). Anthelminthic resistance was detected in two flocks, with EPG reduction of $42 \%$ (BR) and 76\% (ES2) (Table 2).

Four genera of helminths were identified in the coprocultures: Haemonchus, Trichostrongylus, Oesophagostomum, and Teladorsagia. The most common genera were Haemonchus sp. (mean percentage of $68.3 \%$ ), followed by Trichostrongylus (21.9\%), Teladorsagia (7.4\%), and Oesophagostomum (2.5\%). The prevalence of Haemonchus and Trichostrongylus was similar in the pre- and post-treatment coprocultures, indicating high rates of resistance to the molecules tested in these populations (Table 3). It was not possible to perform coproculture in the property located in São Pedro da Serra.

The analysis of the responses to the applied questionnaire indicated that there were no criteria in adopting measures of prevention of gastrointestinal helminths, and all the animals of the flock were treated simultaneously without selective treatment using the FAMACHA method. In $86 \%$ of the flocks, anthelmintic drugs were changed monthly, annually, or without any criteria. In $57 \%$ of the properties, the animals in the flock were acquired from other farms. The number of EPG was counted in $43 \%$ of the herds. However, no anti-helminth test was performed before the study in the evaluated flocks. 


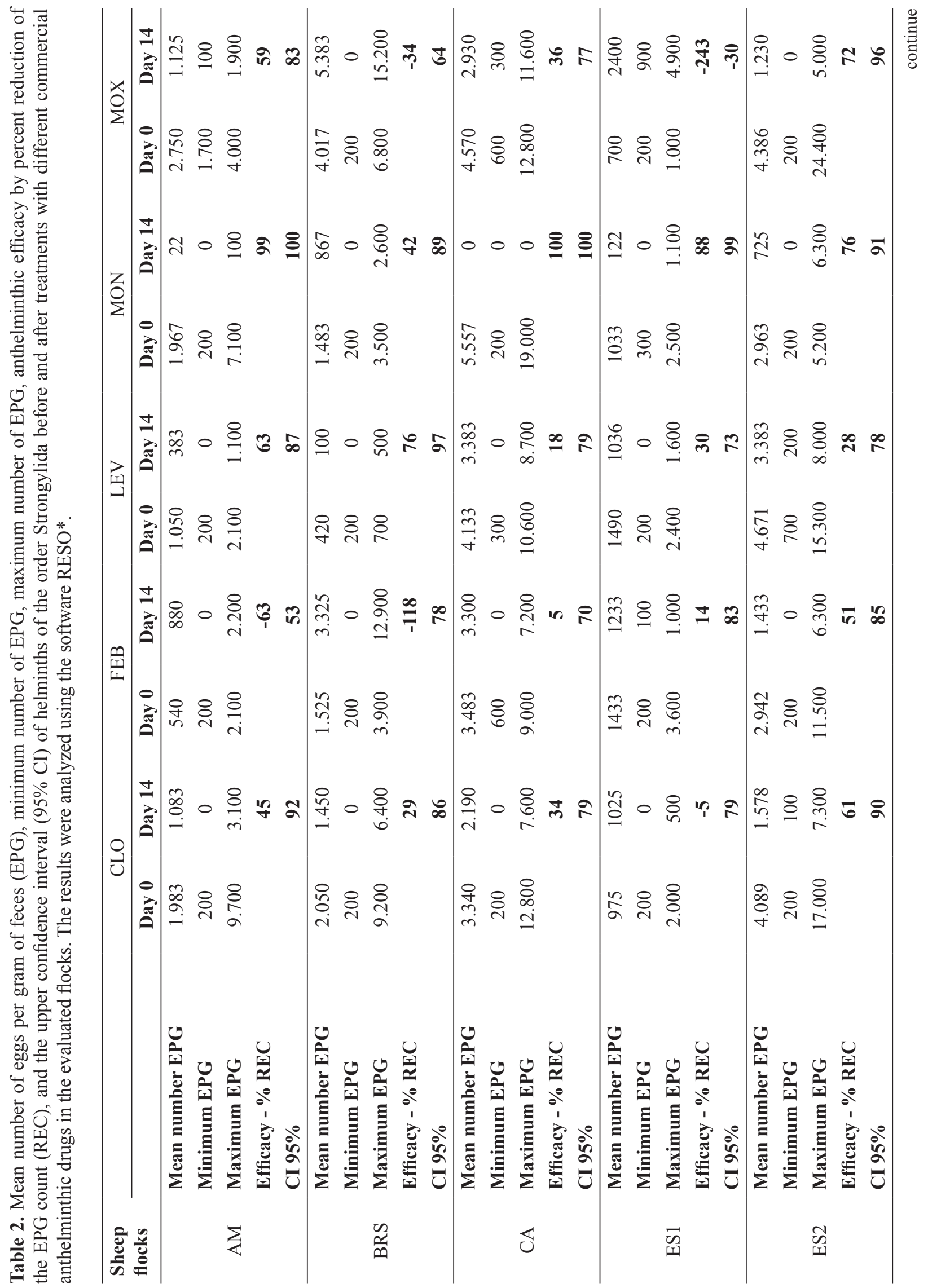




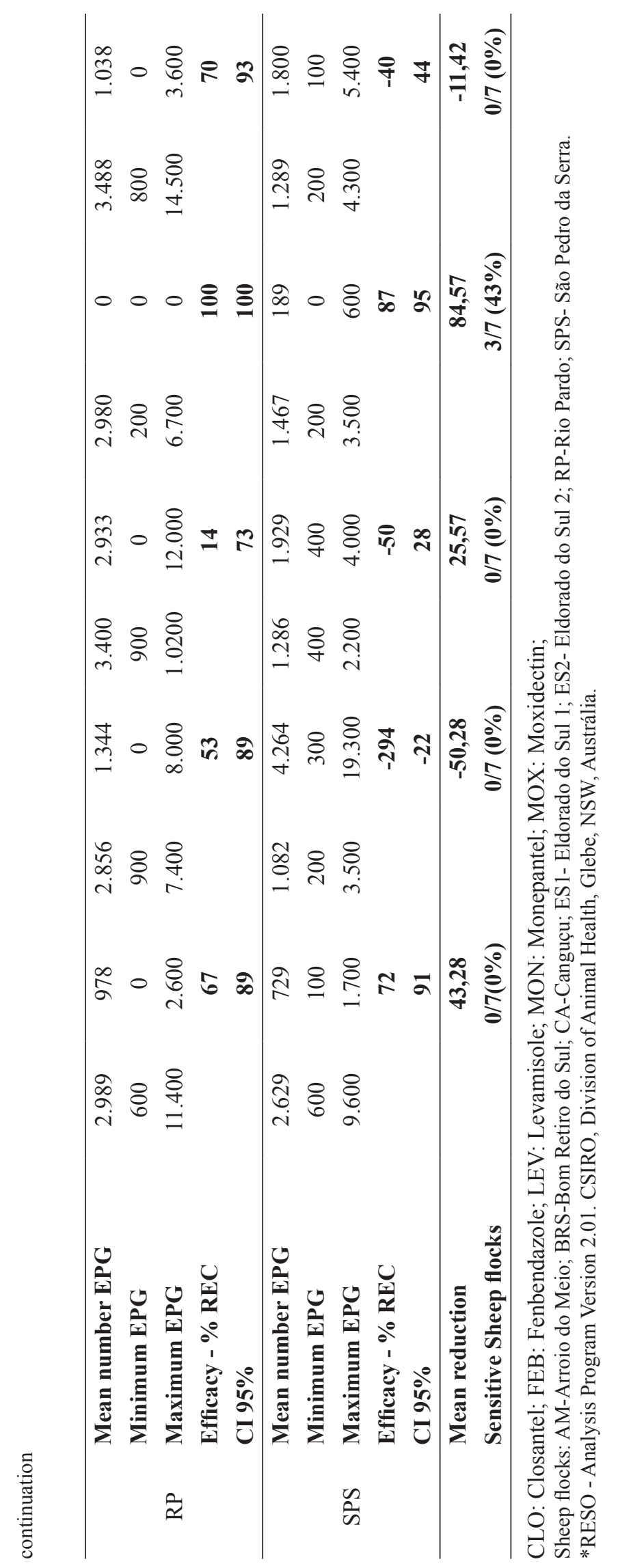


Table 3. Percentage of helminth genes identified in pre- and post-treatment coprocultures in sheep flocks in the state of Rio Grande do Sul, Brazil, tested for resistance to commercial anthelmintic drugs.

\begin{tabular}{|c|c|c|c|c|c|c|c|c|c|}
\hline \multirow{2}{*}{$\begin{array}{l}\text { Sheep } \\
\text { flocks }\end{array}$} & & \multicolumn{2}{|c|}{ Haemonchus } & \multicolumn{2}{|c|}{ Trichostrongylus. } & \multicolumn{2}{|c|}{ Oesophagostomum. } & \multicolumn{2}{|c|}{ Teladorsagia. } \\
\hline & & Day 0 & Day 14 & Day 0 & Day 14 & Day 0 & Day 14 & Day 0 & Day 14 \\
\hline \multirow{5}{*}{$\mathrm{AM}$} & Closantel & 18 & 51,67 & 0 & 0 & 2 & 29 & 80 & 19,33 \\
\hline & Febendazol & 0 & 96 & 90 & 4 & 0 & 0 & 0 & 0 \\
\hline & Levamisol & 0 & 74 & 51 & 10 & 49 & 0 & 0 & 16 \\
\hline & Monepantel & 18 & 6 & 0 & 64 & 2 & 8 & 80 & 22 \\
\hline & Moxidectina & 19 & 44 & 81 & 26 & 0 & 0 & 0 & 30 \\
\hline \multirow{5}{*}{ BRS } & Closantel & 80 & 50 & 20 & 50 & 0 & 0 & 0 & 0 \\
\hline & Febendazol & 73 & 83 & 0 & 4 & 0 & 0 & 27 & 13 \\
\hline & Levamisol & ---- & ---- & ---- & ---- & ---- & ---- & ---- & ---- \\
\hline & Monepantel & ---- & ---- & ---- & ---- & ---- & ---- & ---- & ---- \\
\hline & Moxidectina & 92 & 100 & 8 & 0 & 0 & 0 & 0 & 0 \\
\hline \multirow{5}{*}{$\mathrm{CA}$} & Closantel & ---- & ---- & ---- & ---- & ---- & ---- & ---- & ---- \\
\hline & Febendazol & 98 & 57 & 2 & 0 & 0 & 0 & 0 & 43 \\
\hline & Levamisol & 96 & 30 & 4 & 37 & 0 & 0 & 0 & 33 \\
\hline & Monepantel & 98 & 37 & 2 & 63 & 0 & 0 & 0 & 0 \\
\hline & Moxidectina & 100 & 0 & 0 & 0 & 0 & 0 & 0 & 0 \\
\hline \multirow{5}{*}{ ES1 } & Closantel & 89 & 100 & 11 & 0 & 0 & 0 & 0 & 0 \\
\hline & Febendazol & 10 & 100 & 0 & 0 & 0 & 0 & 90 & 0 \\
\hline & Levamisol & 65 & 100 & 23 & 0 & 11 & 0 & 0 & 0 \\
\hline & Monepantel & 0 & 0 & 0 & 0 & 0 & 0 & 0 & 0 \\
\hline & Moxidectina & 60 & 100 & 40 & 0 & 0 & 0 & 0 & 0 \\
\hline \multirow{5}{*}{ ES2 } & Closantel & 65 & 36 & 35 & 64 & 0 & 0 & 0 & 0 \\
\hline & Febendazol & 65 & 45 & 35 & 55 & 0 & 0 & 0 & 0 \\
\hline & Levamisol & 65 & 26 & 35 & 74 & 0 & 0 & 0 & 0 \\
\hline & Monepantel & 65 & 0 & 35 & 0 & 0 & 0 & 0 & 0 \\
\hline & Moxidectina & 65 & 95 & 35 & 5 & 0 & 0 & 0 & 0 \\
\hline \multirow{6}{*}{$\mathrm{RP}$} & Closantel & 100 & 100 & 0 & 0 & 0 & 0 & 0 & 0 \\
\hline & Febendazol & 98 & 100 & 2 & 0 & 0 & 0 & 0 & 0 \\
\hline & Levamisol & 100 & 100 & 0 & 0 & 0 & 0 & 0 & 0 \\
\hline & Monepantel & 100 & 0 & 0 & 0 & 0 & 0 & 0 & 0 \\
\hline & Moxidectina & 100 & 100 & 0 & 0 & 0 & 0 & 0 & 0 \\
\hline & \% Média Geral & 68,24 & 73,36 & 21,94 & 17,15 & 2,48 & 0,76 & 7,36 & 8,79 \\
\hline
\end{tabular}

Sheep flocks: AM-Arroio do Meio; BRS-Bom Retiro do Sul; CA-Canguçu; ES1- Eldorado do Sul 1; ES2- Eldorado do Sul 2; RPRio Pardo.

\section{Discussion}

There was anti-helminthic resistance to all tested active ingredients and multidrug resistance in all evaluated flocks. Furthermore, there was one report of anthelminthic resistance to monepantel.
Resistance to monepantel in sheep and goats was reported for the first time in New Zealand (SCOTT et al., 2013). Since then, resistance to this product has been detected in Uruguay (MEDEROS et al., 2014) and the Netherlands (VAN DEN BROM et al., 2015), 
and sheep helminths, particularly Haemonchus contortus, are resistant to monepantel in Brazilian breeds (CINTRA et al., 2016; ALBUQUERQUE et al., 2017; MARTINS et al., 2017).

Anti-helminthic resistance is a cause for concern because it may limit sheep farming, reduce the shelf life of the chemical compounds used for control, and jeopardize management strategies (MOLENTO et al., 2004). Monepantel resistance was detected in three of the four farms where the product had never been used. One of the causes of resistance in these cases is the acquisition of animals with drugresistant parasites from properties that have already used monepantel. However, molecular studies are necessary to understand this resistance mechanism, allowing the early detection and development of strategies to prevent the spread of resistant parasites (MEDEROS et al., 2014).

Multidrug resistance was also observed by Waghorn et al. (2006) in New Zealand, Howell et al. (2008) in the United States, and Geurden et al. (2014) in Europe. In South America, Nari et al. (1996) found that approximately $28 \%$ of the farms presented resistance to an anthelmintic drug group, $64 \%$ to two anthelmintic groups, and $1 \%$ resistance to three groups. Only $7.5 \%$ of the properties did not present detectable levels of anthelmintic resistance. Gárcia et al. (2016) determined the efficacy of ivermectin, albendazole, fenbendazole, and levamisole, and observed that animals in properties in Colombia were resistant to all tested active ingredients.

In Brazil, a study by Echevarria et al. (1996) in Rio Grande do Sul reported a critical situation and stressed the need to implement immediate and drastic actions to prevent the decrease in the number of effective anthelmintic drugs in the region with severe consequences. Rosalinski-Moraes et al. (2007) evaluated anthelmintic resistance in Santa Catarina and found that the use of measures of integrated control of parasitoses is essential to prolong the service life of the active principles still available. Almeida et al. (2010) reported that $H$. contortus and T. colubriformis were multiresistant to ivermectin, moxidectin, levamisole, closantel, trichlorfon, and albendazole in sheep. The resistance of gastrointestinal nematodes to anthelminthic drugs in sheep was reported in Mato Grosso do Sul (SCZESNY-MORAES et al., 2010), northeast of Brazil (COSTA et al., 2011), and northern Paraná (HOLSBACK et al., 2013).

In the present study, multidrug resistance may be due to the inadequate management of the sheep flocks, i.e., anthelmintic drugs were used as the only strategy of control of gastrointestinal helminths. The results of the applied questionnaire indicated that the active principles were exchanged monthly, annually, or without any criteria in $86 \%$ of the herds. Amarante et al. (1992) observed that this practice promoted anthelmintic resistance. In 57\% of the evaluated flocks, animals were acquired from other properties. It is known that bringing animals without proper quarantine, anthelmintic treatment, and certification of negative EPG increases anthelmintic resistance because resistant parasites can be transferred to the property (TORRESACOSTA; HOSTE, 2008).

The number of EPG was counted in $43 \%$ of the flocks, but no anti-helminth test was conducted in the evaluated herds before the study. Furthermore, deworming was performed in all study animals without adopting selective treatments. Selective treatment significantly reduces the number of parasites that are present in the environment but are not affected by anthelmintic drugs, favoring the development of resistance. Therefore, it is vital to extend the shelf life of existing products via the strategic and selective use of these products to control parasitism adequately (SCZESNYMORAES et al., 2010).

The most common selective treatment is the FAMACHA method, in which only animals with grade-3, grade-4, or grade-5 infections are treated. However, this technique can only be used in cases 
in which the main parasite is $H$. contortus and the minimum prevalence is $60 \%$ (CHAGAS et al., 2007). Another form of selective treatment is individual EPG examination because it allows identifying the animals that harbor a high number of nematode eggs in the feces (PEREIRA, 2011; TORRES-ACOSTA et al., 2012). This technique may be complex and costly depending on the size of the flock. Alternatively, EPG count may be performed by animal category, and only the animals with EPG of 500-1000 or animals with clinical signs (low-weight animals with diarrhea) are treated (RIET-CORREA et al., 2013).

The results of coprocultures were similar to those found by Buzzulini et al. (2007), whereby the prevalence of $H$. contortus was high in the states of São Paulo, Paraná, Santa Catarina, and Rio Grande do Sul. Similarly, Vieira et al. (2008) reported that the prevalence of Haemonchus ssp. and Trichostrongylus spp. was high in municipalities of Rio Grande do Sul.

The predominance of Haemonchus spp. in pre and post-treatment coprocultures further aggravates the problem of anthelmintic resistance because Haemonchus spp. is the most infective parasite of small ruminants.

\section{Conclusions}

All evaluated flocks were resistant to closantel, fenbendazole, levamisole, and moxidectin, including one report of resistance to monepantel. It is fundamental to raise the awareness of sheep farmers and technicians to use integrated management practices to minimize the exposure of the animals to infective larvae and decrease the use of drugs. The selective treatment of animals should be adopted instead of the general treatment of the flock, extending the effectiveness of anthelmintic drugs. In addition, genetic selection of parasite-resistant animals in the flock should be conducted over the years. One possible approach to select resistant animals is using the FAMACHA method, which, in addition to treating only animals with anemia, can identify and discard animals susceptible to parasites. Animals that present other clinical signs such as diarrhea and less weight gain may also be discarded. Animals with repeated high EPG may be discarded in properties in which the only treatment criterion is EPG count.

\section{Acknowledgements}

The authors thank Laboratório de Helmintologia do Departamento de Patologia Veterinária da Faculdade de Medicina Veterinária UFRGS

\section{References}

AlBUQUeRQue, A. C. A.; BASSETTO, C. C.; ALMEIDA, F. A.; AMARANTE, A. F. Development of Haemonchus contortus resistance in sheep under suppressive or targeted selective treatment with monepantel. Veterinary Parasitology, Amsterdam, v. 246, n. 1, p. 112-117, 2017.

ALMEIDA, F. A.; GARCIA, K. C. O. D.; TORGERSON, P. R.; AMARANTE, A. F. T. Multiple resistance to anthelmintics by Haemonchus contortus and Trichostrongylus colubriformis in sheep in Brazil. Parasitology International, Amsterdam, v. 59, n. 4, p. 622-625, 2010.

AMARANTE, A. F. T.; BARBOSA, M. A.; OLIVEIRA, M. A. G.; CARMELLO, M. J.; PADOVANI, C. R. Efeito da administração de oxfendazol, ivermectina e levamisol sobre os exames coproparasitológicos de ovinos. Brazilian Journal of Veterinary Research and Animal Science, São Paulo, v. 29, n. 1, p. 31-38, 1992.

BESIER, R. B.; LOVE, S. C. J. Anthelmintic resistance in sheep nematodes in Australia: the need for new approaches. Animal Production Science, Sidney, v. 43, n. 12, p. 1383-1391, 2003.

BUZZULINI, C.; SOBRINHO, A. G. S.; COSTA, A. J.; SANTOS, T. R.; BORGES, F. A.; SOARES, V. E. Eficácia anti-helmíntica comparativa da associação albendazole, levamisole e ivermectina à moxidectina em ovinos. Pesquisa Agropecuária Brasileira, Brasília, v. 42, n. 4, p. 891-895, 2007.

CHAGAS, A. C. S.; OLIVEIRA, M. C. S.; CARVALHO, C. O.; MOLENTO, M. B. Método FAMACHAC): um 
recurso para o controle da verminose em ovinos. São Carlos: EMBRAPA Pecuária Sudeste, 2007. 8 p. (Circular técnica, 52).

CINTRA, M. C. R.; TEIXEIRA, V. N.; NASCIMENTO, L. V.; SOTOMAIOR, C. S. Lack of efficacy of monepantel against Trichostrongylus colubriformis in sheep in Brazil. Veterinary Parasitology, Amsterdam v. 216, n. 1, p. 4-6, 2016.

COSTA, V. M. M.; SIMÕES, S. V. D.; RIET CORREA, F. Controle das parasitoses gastrintestinais em ovinos e caprinos na região semiárida do Nordeste do Brasil. Pesquisa Veterinária Brasileira. Seropédica, v. 31, n. 1, p. 65-71, 2011.

ECHEVARRIA, F.; BORBA, M. F.; PINHEIRO, A. C.; WALLER, P. J.; HANSEN, J. W. The prevalence of anthelmintic reistance in nematode parasites of sheep in Southern Latin America: Brazil. Veterinary Parasitology, Amsterdam, v. 62, n. 1, p. 199-206, 1996.

FORTES, F. S.; MOLENTO, M. B. Resistência antihelmíntica em nematoides gastrintestinais de pequenos ruminantes: avanços e limitações para seu diagnóstico. Pesquisa Veterinária Brasileira, Seropédica, v. 33, n. 12, p. 1391-1402, 2013.

GÁRCIA, C. M. B.; SPRENGER, L. K.; ORTIZ, E. B.; MOLENTO, M. B. First report of multiple anthelmintic resistance in nematodes of sheep in Colombia. Anais da Academia Brasileira de Ciências, Rio de Janeiro, v. 88, n. 1, p. 397-402, 2016.

GEURDEN, T.; HOSTE,H.; JACQUIET,P.; TRAVERSA, D.; SOTIRAKI, S.; FRANGIPANE DI REGALBONO, A.; TZANIDAKIS, N.; KOSTOPOULOU, D.; GAILLAC, C.; PRIVAT, S.; GIANGASPERO, A.; ZANARDELLO, C.; NOÉ, L.; VANIMISETTI, B.; BARTRAM, D. Anthelmintic resistance and multidrug resistance in sheep gastro-intestinal nematodes in France, Greece and Italy. Veterinary Parasitology, Amsterdam, v. 201, n. 1, p. 59-66, 2014.

GORDON, H. M. L.; WHITLOCK, H. N. A new technique for counting nematode egg in sheep faeces. Journal of the Council for Scientific and Industrial Research, Melbourne, v. 12, n. 1, p. 50-52, 1939.

HOLSBACK, L.; MARQUEZ, E. S.; MENEGHEL, P. P. Resistência parasitária de helmintos gastrointestinais e avaliação dos parâmetros hematológicos de ovinos no norte do Paraná. Revista Brasileira de Medicina Veterinária, Rio de Janeiro, v. 35, n. 1, p. 76-84, 2013.

HOWELL, S. B.; BURKE, J. M.; MILLER, J. E.; TERRILL, T. H.; VALENCIA, E.; WILLIAMS, M. J.; WILLIAMSON, L. H.; ZAJAC, A. M.; KAPLAN, R. M. Prevalence of anthelmintic resistance on sheep and goat farms in the southeastern United States. Journal of the American Veterinary Medical Association, Ithaca, v. 233, n. 12, p. 1913-1919, 2008.

KAMINSKY, R.; GAUVRY, N.; SCHORDERET, W. S.; SKRIPSKY, T.; BOUVIER, J.; WENGER, A. SCHROEDER, F.; DESAULES, Y.; HOTZ, R.; GOEBEL, T.; HOSKING, B. C.; PAUTRAT, F.; WIELANDBERGHAUSEN, S.; DUCRAY, P. Identification of the amino-acetonitrile derivative monepantel (AAD 1566) as a new anthelmintic drug development candidate. Parasitology Research, New York, v. 103, n. 4, p. 931939, 2008.

MARTINS, A. C.; BERGAMASCO, P. L. F.; FELIPPELLI, G.; TEBALDI, J. H.; DUARTE, M. M. F.; TESTI, A. J. P.; LAPERA, I. M.; HOPPE, E. G. L. Haemonchus contortus resistance to monepantel in sheep: fecal egg count reduction tests and randomized controlled trials. Semina: Ciências Agrárias, Londrina, v. 38, n. 1, p. 231-238, 2017.

MEDEROS, A. E.; RAMOS, Z.; BANCHERO, G. E. First report of monepantel Haemonchus contortus resistance on sheep farms in Uruguay. Parasites \& Vectors, London, v. 7, n. 1, n. 598, p. 1-4, 2014.

MOLENTO, M. B.; TASCA, C.; GALlO, A.; FERREIRA, M.; BONONI, R.; STECCA, E. Método FAMACHAC como parâmetro clínico individual de infecção por Haemonchus contortus em pequenos ruminantes. Ciência Rural, Santa Maria, v. 34, n. 4, p. 1139-1145, 2004.

NARI, A.; SALLES, J.; GIL, A.; WALLER, P. J.; HANSEN, J. W. The prevalence of anthelmintic resistance in nematode parasites of sheep in Southern Latin America: Uruguay. Veterinary Parasitology, Amsterdam, v. 62, n. 1, p. 213-222, 1996.

PEREIRA, C. S. Avaliação da presença de resistência em um rebanho de ovino I no município de Porto Velho. 2011. Dissertação (Mestrado em Saúde Animal) - Universidade de Brasília, Brasília. Disponível em: <http://repositorio. unb.br/handle/10482/8771>. Acesso em: 4 mar. 2016.

RIET-CORREA, B.; SIMÕES, S. V. D.; RIET-CORREA, F. Sistemas produtivos de caprinocultura leiteira no semiárido nordestino: controle integrado das parasitoses gastrointestinais visando contornar a resistência antihelmíntica. Pesquisa Veterinária Brasileira, Seropédica, v. 33, n. 7, p. 901-908, 2013.

ROBERTS, F. H. S.; O'SULLIVAN, J. P. Methods for egg counts and larval cultures for strongyles infesting the gastrointestinal tract of cattle. Australian Journal of Agricultural Research, Melbourne, v. 1, n. 1, p. 99-102, 1950 . 
ROSALINSKI-MORAES, F.; MORETTO, L. H.; BRESOLIN, W. S.; GABRIELLI, I.; KAFER, L.; ZANCHET, I. K.; SONAGLIO, F.; THOMASSOCCOL, V. Resistência anti-helmíntica em rebanhos ovinos da região da associação dos municípios do Alto Irani (Amai), oeste de Santa Catarina. Ciência Animal Brasileira, Goiânia, v. 8, n. 3, p. 559-566, 2007.

SCOTT, I.; POMROY, W. E.; KENYON, P. R.; SMITH, G.; ADLINGTON, B.; MOSS, A. Lack of efficacy of monepantel against Teladorsagia circumcincta and Trichostrongylus colubriformis. Veterinary Parasitology, Amsterdam, v. 198, n. 1, p. 166-171, 2013.

SCZESNY-MORAES, E. A.; BIANCHIN, I.; SILVA, K. F.; CATTO, J. B.; HONER, M. R.; PAIVA, F. Resistência anti-helmíntica de nematóides gastrintestinais em ovinos, Mato Grosso do Sul. Pesquisa Veterinária Brasileira, Seropédica, v. 30, n. 3, p. 229-236, 2010.

TORRES-ACOSTA, J. F. J.; HOSTE, H. Alternative or improved methods to limit gastrointestinal parasitism in grazing sheep and goats. Small Ruminant Research, Amsterdam, v. 77, n. 1, p. 159-173, 2008.
TORRES-ACOSTA, J. F. J.; MENDOZA-DE-GIVES, P.; AGUILAR-CABALLERO, A. J.; CUÉLLAR-ORDAZ, J. A. Anthelmintic resistance in sheep farms: update of the situation in the American continent. Veterinary Parasitology, Amsterdam, v. 189, n. 1, p. 89-96, 2012.

VAN DEN BROM, R.; MOLL, L.; KAPPERT, C.; VELLEMA, P. Haemonchus contortus resistance to monepantel in sheep. Veterinary Parasitology, Amsterdam, v. 209, n. 3, p. 278-280, 2015.

VIEIRA, M. I. B.; ROCHA, H. C.; RACTZ, L. A. B.; NADAL, R.; MORAES, R. B.; OLIVEIRA, I. S. Comparação de dois métodos de controle de nematódeos gastrintestinais em borregas e ovelhas de corte. Semina: Ciências Agrárias, Londrina, v. 29, n. 4, p. 853-860, 2008.

WAGHORN, T. S.; LEATHWICK, D. M.; RHODES, A. P.; LAWRENCE, K. E.; JACKSON, R.; POMROY, W. E.; WEST, D. M.; MOFFAT, J. R. Prevalence of anthelmintic resistance on sheep farms In New Zealand. The New Zealand Veterinary Journal, Wellington, v. 54, n. 6, p. 271-277, 2006.

ZAJAC, A. M.; CONBOY, G. A. Veterinary clinical parasitology. $7^{\text {th }}$ ed. Ames: Blackwell Publishing, 2006. $320 \mathrm{p}$ 
